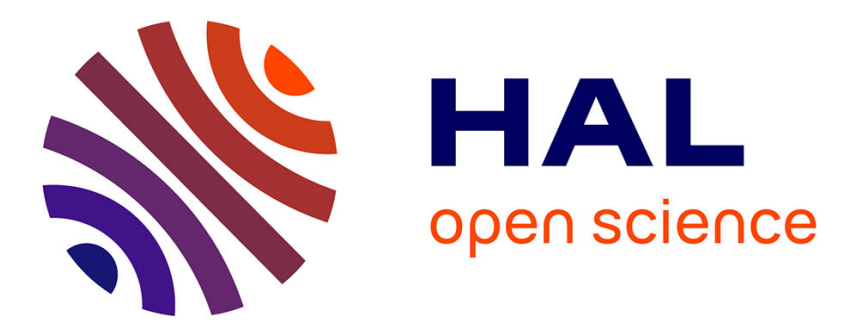

\title{
Is $\delta$-aminolevulinic acid dehydratase activity in bivalves from south-west Iberian Peninsula a good biomarker of lead exposure?
}

Judit Kalman, Inmaculada Riba, Julián Blasco, T. Ángel Delvalls

\section{- To cite this version:}

Judit Kalman, Inmaculada Riba, Julián Blasco, T. Ángel Delvalls. Is $\delta$-aminolevulinic acid dehydratase activity in bivalves from south-west Iberian Peninsula a good biomarker of lead exposure?. Marine Environmental Research, 2008, 66 (1), pp.38. 10.1016/j.marenvres.2008.02.016 . hal-00501944

\author{
HAL Id: hal-00501944 \\ https://hal.science/hal-00501944
}

Submitted on 13 Jul 2010

HAL is a multi-disciplinary open access archive for the deposit and dissemination of scientific research documents, whether they are published or not. The documents may come from teaching and research institutions in France or abroad, or from public or private research centers.
L'archive ouverte pluridisciplinaire HAL, est destinée au dépôt et à la diffusion de documents scientifiques de niveau recherche, publiés ou non, émanant des établissements d'enseignement et de recherche français ou étrangers, des laboratoires publics ou privés. 


\section{Accepted Manuscript}

Is $\delta$-aminolevulinic acid dehydratase activity in bivalves from south-west Iberian Peninsula a good biomarker of lead exposure?

Judit Kalman, Inmaculada Riba, Julián Blasco, T. Ángel DelValls

PII:

S0141-1136(08)00031-7

DOI:

10.1016/j.marenvres.2008.02.016

Reference:

MERE 3183

To appear in:

Marine Environmental Research

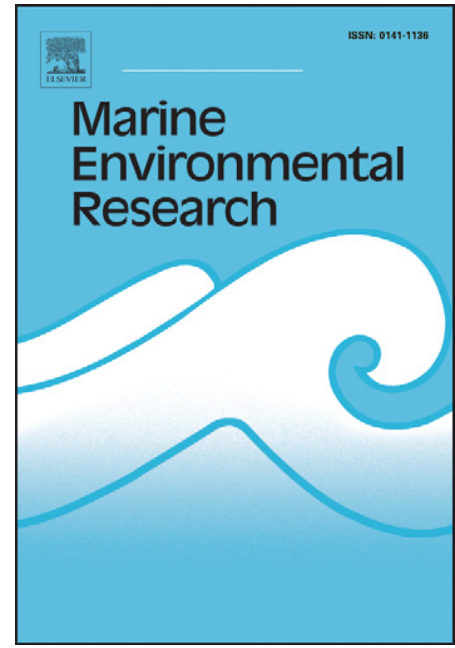

Please cite this article as: Kalman, J., Riba, I., Blasco, J., Ángel DelValls, T., Is $\delta$-aminolevulinic acid dehydratase activity in bivalves from south-west Iberian Peninsula a good biomarker of lead exposure?, Marine Environmental Research (2008), doi: 10.1016/j.marenvres.2008.02.016

This is a PDF file of an unedited manuscript that has been accepted for publication. As a service to our customers we are providing this early version of the manuscript. The manuscript will undergo copyediting, typesetting, and review of the resulting proof before it is published in its final form. Please note that during the production process errors may be discovered which could affect the content, and all legal disclaimers that apply to the journal pertain. 


\title{
Is $\delta$-aminolevulinic acid dehydratase activity in bivalves from south-west Iberian Peninsula a good biomarker of lead
} exposure?

\author{
Judit Kalman ${ }^{\text {a,b }}$, Inmaculada Riba ${ }^{\text {a,b }}$, Julián Blasco a, T. Ángel \\ DelValls ${ }^{\mathbf{b}^{*}}$ \\ ${ }^{a}$ Instituto de Ciencias Marinas de Andalucía. CSIC Polígono Río San Pedro s/n. 11510 Puerto Real \\ (Cádiz). Spain. \\ ${ }^{b}$ Cátedra UNESCO/UNITWIN/WiCop. Facultad de Ciencias del Mar y Ambientales. Universidad de \\ Cádiz. Polígono Río San Pedro s/n. 11510 Puerto Real Spain.
}

\begin{abstract}
The coast of Huelva is considered as a heavily contaminated area where the Tinto and Odiel rivers discharge after running through a metalliferous mining area in the Iberian Pyrite Belt and end in common estuary called Ría of Huelva. Lead is a highly toxic and widely distributed element in the aquatic environment; therefore there is a great interest in assessing the impact of this contaminant on aquatic organisms. To study the bioavailability and sources of lead, the bivalve species Chamelea gallina was collected from six sampling sites along the coast of Huelva. Besides the effect of this metal on the enzyme activity, $\delta$-aminolevulinic acid dehydratase (ALA-D) was
\end{abstract}


determined in the whole tissue. Results show the inverse relationship between the lead concentration and the activity of ALA-D measured in whole tissues $\left(\mathrm{r}^{2}=0.7\right)$. Individuals collected from the Ría of Huelva estuary had the highest levels of total lead concentrations and the lowest activity of ALA-D. Lead isotope analyses demonstrated the different sources of lead contamination and also confirmed the influence of Ría of Huelva on the metal input to the marine environment.

Keywords: ALA-D activity; Bivalve; Lead; Coast of Huelva

*Corresponding autor: Tel.: +34-956-016040; fax: +34-956-016040

E-mail address: angel.valls@uca.es

Lead is a highly toxic contaminant due to its ability to accumulate in living organisms and inhibit the activities of essential enzymes. The main sources are mining and industrial activities, sewage waste and the remains of leaded gasoline used in the past. The study area, the coast of Huelva, is situated on the Iberian Pyrite Belt, which is one of the most famous sulfide mining regions in the world. The coast receives considerable fluvial contaminant input from Ría of Huelva formed from the Odiel and Tinto Rivers (Machado et al., 2005). Pb contamination of the study area is related to sulfide minerals outflow which, besides wastes from the industrial complex located at the junction of the two rivers, contribute to considerable lead input to the marine environment (Martins et al., 2007). The epibenthic suspension feeder, Chamelea gallina is abundant along the whole Atlantic coast of southern Spain and highly appreciated for human consumption (Usero et al., 2005). The activity of $\delta$-aminolevulinic acid 
dehydratase (ALA-D) is considered as a specific and useful biomarker of lead pollution (Aisemberg et al., 2005). This enzyme catalyzes the condensation of two molecules of $\delta$-aminolevulinic acid to porphobilinogen (PBG), which is an important step in the heme biosynthesis. In the presence of this pollutant the activity of ALA-D is inhibited. To investigate the influence of lead contamination and its adverse biological effect, bivalves were collected along the coast of Huelva and total lead concentration and activity of ALA-D were determined in the whole tissues. This survey was carried out as a part of a multidisciplinary study (INTERREG IIIA, UTPIA) to investigate the distribution and sources of lead. In the framework of this project lead isotopes $(204 \mathrm{~Pb}$, $206 \mathrm{~Pb}, 207 \mathrm{~Pb}, 208 \mathrm{~Pb}$ ) were determined to identify the origins of lead contaminant.

Figure 1 shows a map indicating the six sampling sites. At each sampling site approximately twenty individuals were collected. Three of them were frozen individually in liquid nitrogen immediately after dissection, and the rest (about seventeen organisms) were placed in plastic containers filled with seawater and transferred to the laboratory. Samples for analysis of ALA-D inhibition were stored at $80^{\circ} \mathrm{C}$, while samples for lead determination were placed in clean aerated seawater for 48 $\mathrm{h}$ to depurate the digestive tract. After dissection pooled samples were freeze-dried and prepared for total $\mathrm{Pb}$ and lead isotope analyses. In our laboratory total lead concentration was determined in duplicate by ICP-OES (Optima 2000 DV, Perkin Elmer), bicinchoninic acid assay (Smith et al., 1985) was used for the measurement of total protein concentration and the method described by Nakagawa et al. (1994) was followed for determination of the inhibition of ALA-D. The identification of distinctive isotope compositions of lead was carried out by GEOMEDIC Laboratory using multi collector ICP-MS. 
Total lead concentrations were highest in samples collected near the estuarine mouth $\left(1.58 \mu \mathrm{g} \mathrm{g}^{-1} \mathrm{~d}\right.$.w. for stations 1$)$, while organisms found further from the river outflows accumulated less lead (0.60-0.84 $\mu \mathrm{g} \mathrm{g}^{-1}$ d.w.). Although C. gallina is commonly found not only the Atlantic coast, but also in the Mediterranean Sea, limited surveys were conducted on the bioaccumulation of lead. Castro et al. (1999) recorded much lower lead concentrations in C. gallina (0.07-0.30 $\left.\mu \mathrm{g} \mathrm{g}^{-1} \mathrm{~d} . \mathrm{w}.\right)$ collected from fishing areas located in the coast of Almería (SE Spain), suggesting that coast of Huelva is a heavily lead-contaminated area. It is well established that higher concentration of $\mathrm{Pb}$ causes higher inhibition of ALA-D (Hodson et al., 1984), which is in accordance with our findings, as the lowest activities of ALA-D were found in tissues collected from the estuarine mouth (Fig. 2). For several reasons it is difficult to compare our results to other reports; most studies were performed in the blood or particular tissues of vertebrates and not in the whole tissues; moreover the experiment-related variables (acclimation period, temperature) differed as well. ALA-D inhibition was determined by Campana et al. (2003) in the blood, liver and kidneys of Halobatrachus didactylus, with considerably higher levels obtained than those of the present study $(7.54 ; 37.7$; $75.4 \mathrm{ngPBG} / \mathrm{min} / \mathrm{mg}$ protein). The strong inverse relationship $\left(\mathrm{r}^{2}=0.7\right)$ between ALA-D and $\mathrm{Pb}$ concentrations found in this survey also confirms that ALA-D inhibition increased with the increase of $\mathrm{Pb}$ concentrations. The activity of this enzyme is sensitive to a variety of metals due to its sulfhydryl groups; therefore to propose the activity of ALA-D as a specific biomarker for lead contamination, further investigation is required. Alves Costa et al. (2007) found that the activity of ALA-D in blood of the fish Hoplias malabaricus was affected not only by lead but by methylmercury as well.

The isotope studies indicated that the anthropogenic lead input is related to mining and industrial activities. On the other hand the strong increase in $206 \mathrm{~Pb} / 204 \mathrm{~Pb}$ 
ratio with decreasing lead contamination also confirms that Ría of Huelva contributes to the lead input into the marine ecosystem on a large scale (Martins et al., 2007).

\section{Acknowledgement}

This work has been funded by the joint contract between the University of Huelva and the Instituto de Ciencias Marinas de Andalucía, CSIC under INTERREG IIIA, UTPIA, framework. 


\section{References}

Aisemberg, J., Nahabedian, D.E., Wider, E.A., and Verrengia Guerrero, N.R. (2005). Toxicology, 210, 45-53.

Alves Costa, J.R.M., Mela, M., Assis, H.C.S., Pelletier, E., Randi, R.F., and Oliveira Ribeiro, C.A. (2007). Ecotoxicology and Environmental Safety, 67, 82-88.

Campana, O., Sarasquete, C., and Blasco, J. (2003). Ecotoxicology and Environmental Safety, 55, 116-125.

Castro, H., Aguilera, P.A., Martinez Vidal, J.L., and Carrique, E.L. (1999). Environmental Monitoring and Assessment, 54, 229-237.

Hodson, P.V., Blunt, B.R., Whittle, D.R. (1984). In Cairns, V.W., Hodson, P.V. \& Nriagu, J.O., eds. Contaminant Effects on Fisheries, (pp 87-98). Wiley, New York. Machado, A., Rocha, F., Araújo, M.F., Vitali, F., Gomes, C., and Dias, J.A. (2005). Ciencias Marinas, 31, 161-177.

Martins, L., Batista, M.J., Matos, J., Oliveira, D., Shepherd, T.J., Abreu, M.M. et al. (2007). VI Congresso Ibérico de Geoquímica. Oviedo, Spain.

Nakagawa, H., Sato, T., and Kubo, H. (1995). Fisheries Science, 61, 97-99.

Smith, P.L., Krohn, R.I., Hermanson, G.T., Mallia, A.K., Gartner, F.H., Provenzano, M.D. et al. (1985). Analytical Biochemistry, 150, 76-85.

Usero, J., Morillo, J., and Gracia, I. (2005). Chemosphere, 59, 1175-1181. 


\section{Figure Captions}

Fig. 1. Map of the studied area in southwest Spain showing the locations of six sampling sites selected along the coast of Huelva.

Fig. 2. Relationship between the activity of ALA-D (ng PBG $\min ^{-1} \mathrm{mg} \operatorname{prot}^{-1}$ ) and $\mathrm{Pb}$ concentration ( $\mu \mathrm{g} \mathrm{g}^{-1}$ d.w.) measured in the whole tissues of Chamelea gallina. Vertical error bars represent the standard deviation about the mean of three determinations, while horizontal error bars represent the standard deviation about the mean of two determinations. 


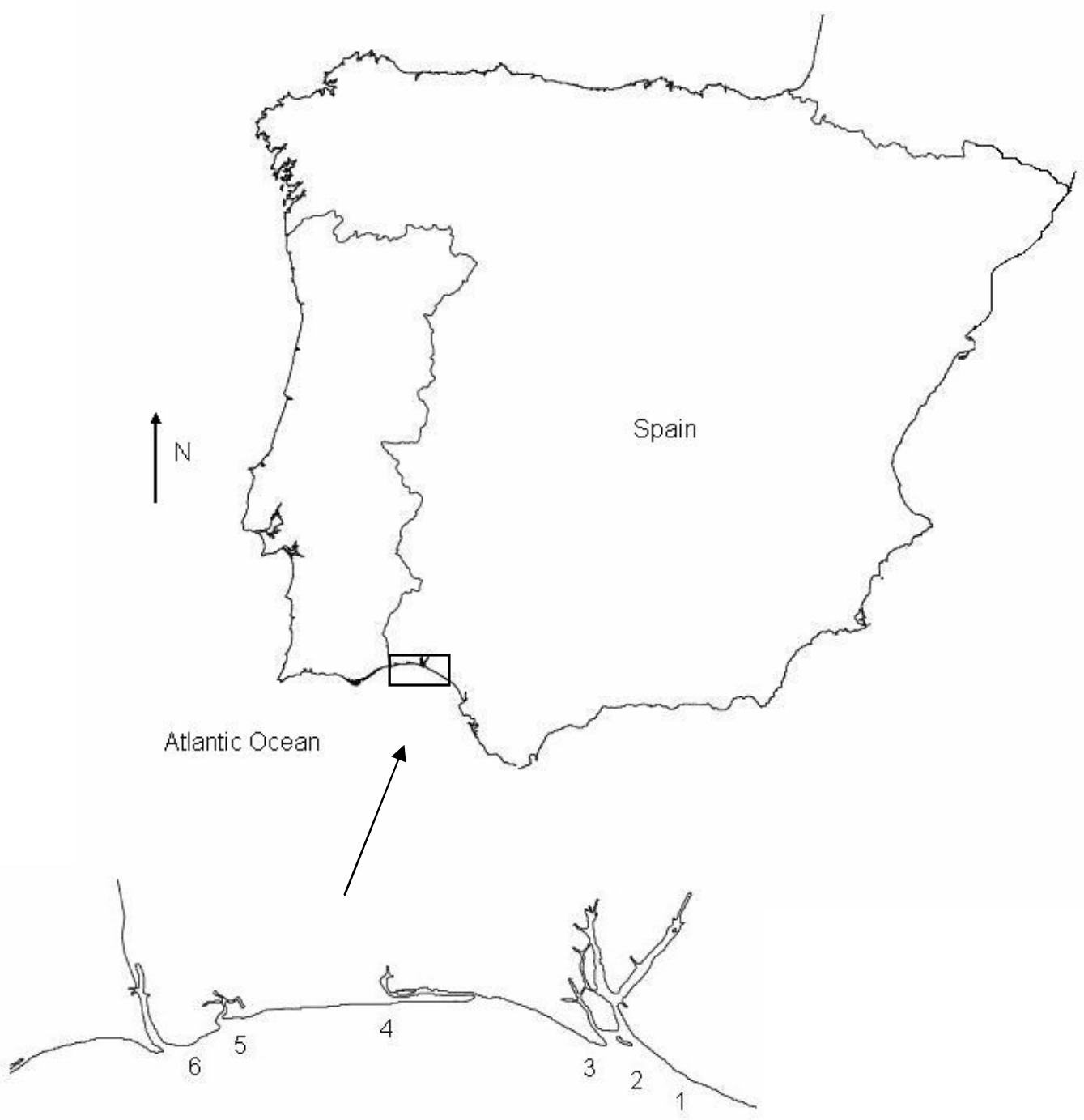

Figure 1. 


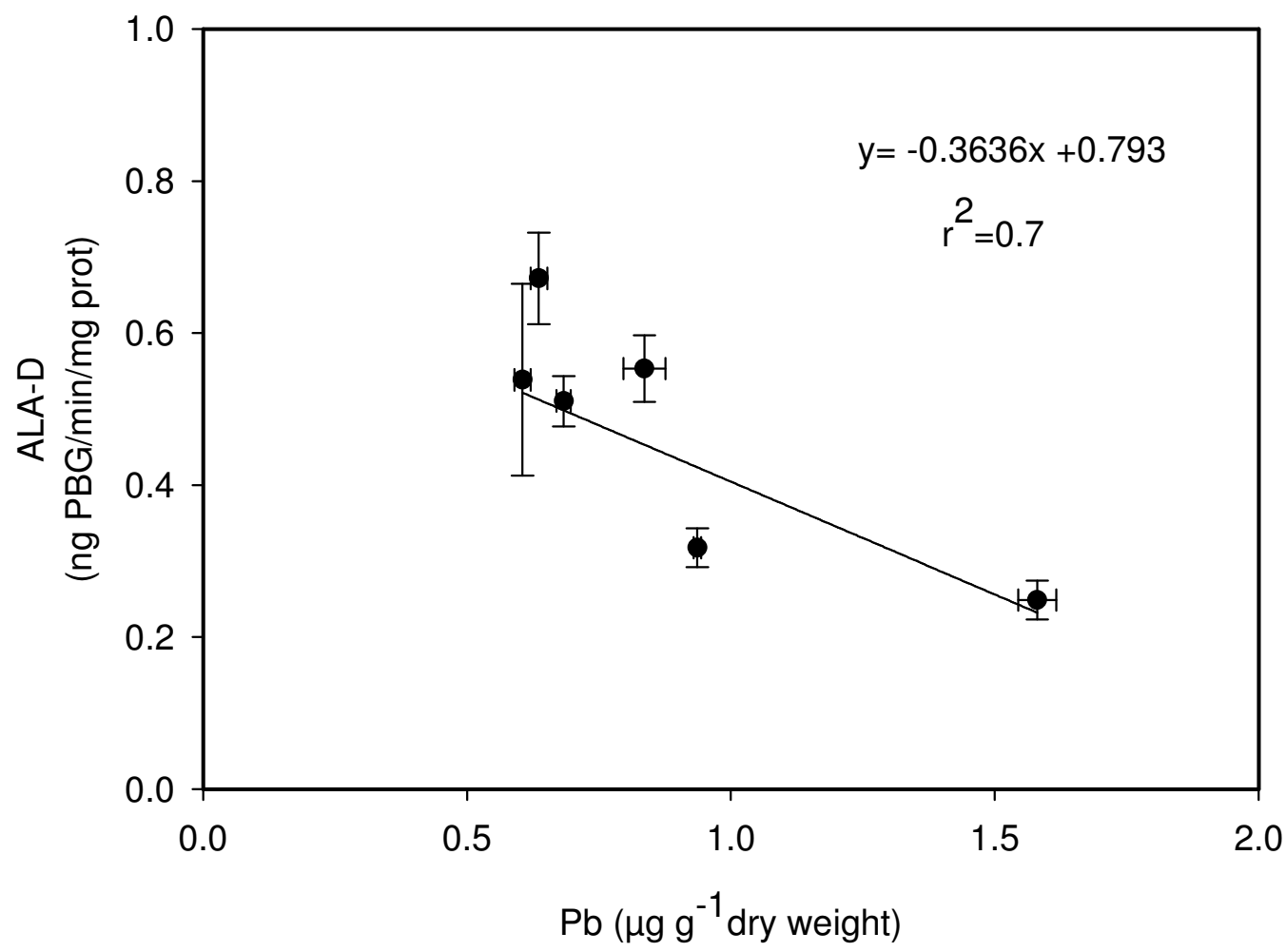

Figure 2. 